International Research Journal of Management, IT \& Social Sciences
Available online at https://sloap.org/journals/index.php/irjmis/
Vol. 8 No. 3, May 2021, pages: 256-264
ISSN: 2395-7492
https://doi.org/10.21744/irjmis.v8n3.1611

\title{
Effect of Corporate Governance on Expropriation Practices with Family Ownership as Moderation Variable
}

\author{
Gladys Bella Novenna Rettob ${ }^{\text {a }}$ \\ Imam Subekti ${ }^{\text {b }}$ \\ Endang Mardiati ${ }^{\mathrm{c}}$
}

Article history:

Submitted: 9 February 2021

Revised: 18 March 2021

Accepted: 27 April 2021

\section{Keywords:}

corporate governance; expropriation practices; family ownership;

\begin{abstract}
The practice of expropriation is one of the accounting frauds committed by controlling shareholders because of their control rights that exceed cash flow rights. This study aims to examine and analyze the effect of corporate governance on the practice of expropriation and the existence of family ownership as a moderating variable. This research was conducted at companies in all sectors of the Indonesia Stock Exchange. Based on the purposive sampling method, the sample of this study was 78 companies with 312 observations. The research data were analyzed using multiple regression analysis. The results of this study indicate that the practice of expropriation in Indonesia can be minimized by implementing adequate corporate governance. The results of this study also prove that companies whose shareholding structures are dominated by the family will maintain control in the company through their management so that they have an impact on limiting governance practices in reducing expropriation practices.
\end{abstract}

International research journal of management, IT and social sciences (C) 2021. This is an open access article under the CC BY-NC-ND license (https://creativecommons.org/licenses/by-nc-nd/4.0/).

\section{Corresponding author:}

Rettob, G. B. N.

Faculty of Economics and Business, Universitas Brawijaya, Indonesia

Jalan Veteran, Malang, Jawa Timur 65145, Indonesia

Email address: gladysrettob021194@gmail.com

\footnotetext{
a Faculty of Economics and Business, Universitas Brawijaya, Indonesia

${ }^{\mathrm{b}}$ Faculty of Economics and Business, Universitas Brawijaya, Indonesia Faculty of Economics and Business, Universitas Brawijaya, Indonesia 


\section{Introduction}

The practice of expropriation is one of the accounting frauds that often occurs in Indonesia. This is because Indonesia is one of the countries that apply its laws based on civil law (Subekti, 2012). The characteristic of a country that implements civil law is that the protection of outside investors in the capital market is weak (Hung, 2000). The weakness of the legal system in Indonesia has an impact on accounting applications, namely the existence of opportunities for controlling shareholders to practice expropriation by arranging transactions that are detrimental to minority shareholders (non-controlling shareholders) (Subekti, 2012).

This conflict between controlling shareholders and non-controlling shareholders is known as a type II agency problem (Du et al. 2013; Fernando et al. 2013). The shift of the agency problem, which was originally between the company owner (principal) and the manager (agent) of the company to the agency problem between controlling shareholders and non-controlling shareholders, is based on the fact that most large companies in various countries including Indonesia tend to have concentrated share ownership and dominated by families (Shleifer \& Vishny, 1997; La Porta et al. 1999; Claessens et al. 2000).

The fact that Indonesia is dominated by family companies affiliated with this business group is what encourages the practice of expropriation of minority shareholders in Indonesia. This is confirmed by Subekti (2012) which states that expropriation of non-controlling shareholders will be easier for companies that are affiliated in one business group compared to companies that are not affiliated in one (single) business group. Claessens et al. (2002) explained that, when the company's ownership structure is concentrated or in the form of a business group, the controlling shareholder in the company will have the ability to direct various company policies. This is because, in companies with a concentrated shareholding structure, controlling shareholders have more information about the company, and controlling shareholders can increase their control rights over companies with low cash flow rights (Claessens et al. al., 2002). Fan \& Wong (2002) stated that this condition can lead to entrenchment problems, namely the actions of controlling shareholders protected by their control rights to expropriate non-controlling shareholders.

Problems related to the occurrence of expropriation by the majority shareholder can be limited. Limiting expropriation by the majority shareholder can be done by applying adequate corporate governance. The implementation of governance can be used to reduce the opportunistic behavior of the company management. Research related to the effect of corporate governance on expropriation practices has been investigated by several previous researchers. Research by Hamid et al. (2016) who examined the effect of independent boards of commissioners, audit committees, and non-duality CEOs on expropriation practices, showed that corporate governance mechanisms in 100 public companies in Malaysia were able to prevent expropriation practices against minority shareholders. Fakkriyah et al. (2017) through their research also proves that the practice of expropriation can be minimized by implementing good governance. In contrast to the results of research conducted by Hamid et al. (2016) and Fakkriyah et al. (2017), research conducted by Hastori et al. (2015) show that the board of directors and the board of commissioners can reduce the practice of expropriation, but independent commissioners and audit committees are not significant factors in reducing expropriation practices. Research by Sari et al. (2014) also concluded that the overall governance mechanisms (ownership structure, independent directors, and audit committee) in companies that perform tunneling or not tunneling cannot be differentiated so that governance mechanisms are not an effective factor in preventing tunneling as a form of practice. expropriation.

Previous studies tested conventional governance only partially because it is necessary to have a measure of governance that is more effective. This study uses governance measurements following the aspects, principles, and recommendations of corporate governance based on the Financial Services Authority Circular Letter No. 32/SEOJK.04/2015 concerning Guidelines for Governance of Public Companies, to bring up overall governance results that are expected to be more effective. Several previous research results related to the effect of corporate governance on expropriation practices show inconsistent results. Bridging the inconsistent research results, this study adds a moderating variable that is expected to strengthen or weaken the influence of corporate governance on expropriation practices. The moderating variable in this study is family ownership. Family ownership is expected to moderate the influence of corporate governance on expropriation practices.

Literature Review

Agency theory

Conflicts in agency relationships that occur between principals and agents are found in large companies in the United States, England, and Japan (Berle \& Means, 1932; Jensen \& Meckling, 1976). It stocks tend to be concentrated and

Rettob, G. B. N., Subekti, I., \& Mardiati, E. (2021). Effect of corporate governance on expropriation practices with family ownership as moderation variable. International Research Journal of Management, IT and Social Sciences, 8(3), 256-264. https://doi.org/10.21744/irjmis.v8n3.1611 
dominated by family or government (Shleifer \& Vishny, 1997; La Porta et al., 1999; Claessens et al., 2000). The concentrated form of company ownership causes the shift of agency problems, which initially between company owners and company managers, to between controlling company owners or majority shareholders and non-controlling company owners or minority shareholders, which is also known as the Type II agency problem (Shleifer \& Vishny, 1997; La Porta et al., 1999).

The agency problem between controlling shareholders and non-controlling shareholders arises from the separation of cash flow rights from control rights (Bechuk et al., 1999; Mitton, 2002; Siregar \& Utama, 2008). When cash flow rights and control rights are separate, the controlling shareholder can control the company beyond its ownership. This makes controlling shareholders have the ability to direct various company policies according to their interests which results in non-controlling shareholders not getting what they are entitled to or what is known as the entrenchment effect (Claessens et al., 2002). Through the entrenchment effect argument, it is known that controlling shareholders use their ability to control the company's management for personal gain by expropriating non-controlling shareholders. The expropriation carried out by controlling shareholders towards non-controlling shareholders makes agency theory the main basis of this research.

\section{Hypothesis Formulation}

The effect of corporate governance on expropriation practices

Agency problems in companies in Indonesia occur between controlling shareholders and their minority shareholders, this conflict is known as agency problem type II (Villalonga \& Amit, 2006). The agency problem between controlling shareholders and non-controlling shareholders arises from the separation of cash flow rights from control rights (Bechuk et al., 1999). Higher control rights than cash flow rights lead to a higher probability of expropriation practices (Jensen et al., 2000; Claessens et al., 2002; \& Baek et al., 2004).

The solution to limit the opportunistic behavior of the majority shareholder can be done by implementing adequate corporate governance. This is based on the agency theory approach, which proposes that there needs to be a monitoring mechanism which is assumed to be able to reduce conflicts of interest between majority shareholders and minority shareholders and prevent opportunistic behavior by controlling shareholders, including acts of expropriation (Jensen \& Meckling, 1976). The results of research conducted by Hamid et al. (2016) proved that corporate governance is a supervisory mechanism within the company, which oversees the company's business activities to safeguard the interests of all stakeholders. Based on these descriptions, the research hypotheses formulated are:

H1: Governance has a negative effect on expropriation practices.

\section{Family ownership on the effect of corporate governance on expropriation practices}

Business groups controlled by families through a pyramid ownership structure tend to expropriate shareholders, not controllers. Entrenchment problems can also occur if the family as the founder of the company (founder family) has small share ownership in the parent company, but has sufficient control rights so that they can exercise control over the subsidiary through their share ownership. Family members of the founder family who occupy a position as the top leader have the right to control so that they are not easily subject to disciplinary sanctions.

The majority shareholder, in this case, the family tends to maintain its dominance in the company, through its management and also restrictions on governance practices (Claessens et al., 2000). Restrictions on governance practices ultimately limit the protection of minority shareholders, this is against the principles of corporate governance which aim to provide equal treatment to all shareholders. Finally, this conflict of interest leads to expropriation by the majority shareholder and their families against minority shareholders, with poor corporate governance practices. This causes governance practices to tend not to work properly and company policies that are taken are more likely to prioritize the controlling interests of the company, namely the family, and harm minority shareholders (Haque et al., 2011). The results of research by Wirawan \& Diyanty (2014) state that family ownership is empirically proven to have a negative effect on the implementation of corporate governance, which means that the implementation of corporate governance with a high proportion of family ownership will not be carried out properly. Based on these descriptions, the research hypotheses formulated are:

H2: Family ownership weakens the negative influence of corporate governance on expropriation practices. 


\section{Materials and Methods}

This research uses a quantitative approach with an explanatory research type with an associative form of research. The population of this study is all companies in 2016-2019 with the sample criteria and the number of samples obtained are presented in Table 1 . The dependent variable, namely the practice of expropriation in this study, is measured by changing the form of related party sales transactions to a natural logarithmic form. The independent variable, namely corporate governance, is measured by dividing the number of recommendations that have been implemented by the company divided by the total recommendations (25 recommendations) based on SE OJK No. 32/SEOJK.04/2015. Family ownership is a moderating variable in this study. This study uses the ultimate approach in measuring family ownership because it can trace down to the final shareholder. The control variable in this study was determined based on the research of Kustiyaningrum et al. (2016) and research by Rahman \& Sunarti (2017), namely company size, profitability, leverage in Table 1.

Table 1

Sample Selection Procedure

\begin{tabular}{cll}
\hline No. & Criteria & Total \\
\hline 1. & Public companies listed on the IDX in the 2016-2019 period. & 715 \\
2. & Companies that publish annual reports in a row during the 2016 - 2019 & $(336)$ \\
& period. & $(64)$ \\
3 & Companies whose reporting currency is in Indonesian Rupiah (Rp). & $(237)$ \\
4 & Companies that make sales with related parties. & 78 \\
The number of companies used as research samples. & 312 \\
The number of observations for 4 years (2016-2019). &
\end{tabular}

\section{Results and Discussions}

\section{Descriptive Statistics}

The results of the descriptive statistics of the variables of this study show an overview of the data under study, namely the minimum, maximum, average, and standard deviation presented in Table 2.

Table 2

Descriptive Statistics Results

\begin{tabular}{lllll}
\hline Variable & Minimum & Maximum & Average & Standard Deviation \\
\hline Practice of Expropriation & 7,50 & 13,51 & 10,9102 & 1,30481 \\
Corporate governance & 0,00 & 0,43 & 0,1789 & 0,12763 \\
Family Ownership & 0,00 & 1,00 & 0,5071 & 0,37386 \\
Company Size & 11,15 & 14,07 & 12,5758 & 0,65468 \\
Leverage & 0,09 & 0,92 & 0,4493 & 0,19981 \\
Profitability & $-0,040$ & 0,69 & 0,551 & 0,09454 \\
\hline
\end{tabular}

\section{Regression Analysis Results}

This study uses two types of regression analysis, namely Hierarchical Moderated Regression. The results of the regression model for the effect of Governance (TK) on Expropriation Practices (Y) which are moderated by Family Ownership (KK) can be seen in Table 3.

Rettob, G. B. N., Subekti, I., \& Mardiati, E. (2021). Effect of corporate governance on expropriation practices with family ownership as moderation variable. International Research Journal of Management, IT and Social Sciences, 8(3), 256-264. https://doi.org/10.21744/irjmis.v8n3.1611 
Table 3

Regression Model Analysis Results

\begin{tabular}{|c|c|c|c|c|}
\hline \multicolumn{5}{|c|}{ Equation 1} \\
\hline Variable & $\beta$ & Std. Error & $\mathrm{t}$ count & p-value \\
\hline (Constant) & 1.006 & 1.434 & 0.702 & 0.483 \\
\hline TK & -1.322 & 0.564 & -2.344 & 0.020 \\
\hline SIZE & 0.835 & 0.112 & 7.479 & 0.000 \\
\hline ROA & -1.236 & 0.740 & -1.669 & 0.096 \\
\hline LEV & -0.659 & 0.342 & -1.929 & 0.055 \\
\hline $\mathrm{R}^{2}$ & 0.227 & & & \\
\hline $\operatorname{Adj} R^{2}$ & 0.217 & & & \\
\hline F count & 22.557 & & & \\
\hline p-value & 0.000 & & & \\
\hline \multicolumn{5}{|c|}{ Equation 2} \\
\hline Variable & $\beta$ & Std. Error & $t$ count & $p$-value \\
\hline (Constant) & 2.015 & 1.309 & 1.539 & 0.125 \\
\hline TK & -1.904 & 0.518 & -3.676 & 0.000 \\
\hline KK & 1.313 & 0.162 & 8.100 & 0.000 \\
\hline SIZE & 0.704 & 0.103 & 6.846 & 0.000 \\
\hline ROA & -1.258 & 0.673 & -1.870 & 0.062 \\
\hline LEV & -0.470 & 0.311 & -1.509 & 0.132 \\
\hline $\mathrm{R}^{2}$ & $=0.364$ & & & \\
\hline $\operatorname{Adj} R^{2}$ & $=0.353$ & & & \\
\hline F count & $=34.966$ & & & \\
\hline p-vlaue & $=0.000$ & & & \\
\hline \multicolumn{5}{|c|}{ Equation 3} \\
\hline Variable & $\beta$ & Std. Error & $\mathrm{t}$ count & p-value \\
\hline (Constant) & 3.111 & 1.323 & 2.351 & 0.019 \\
\hline TK & -4.281 & 0.850 & -5.037 & 0.000 \\
\hline $\mathrm{KK}$ & 0.512 & 0.279 & 1.832 & 0.068 \\
\hline $\mathrm{TK} * \mathrm{KK}$ & 4.483 & 1.284 & 3.492 & 0.001 \\
\hline SIZE & 0.649 & 0.102 & 6.346 & 0.000 \\
\hline ROA & -1.308 & 0.661 & -1.978 & 0.049 \\
\hline LEV & -0.450 & 0.306 & -1.469 & 0.143 \\
\hline $\mathrm{R}^{2}$ & 0.388 & & & \\
\hline $\operatorname{Adj} R^{2}$ & 0.376 & & & \\
\hline F count & 32.236 & & & \\
\hline$p$-value & 0.000 & & & \\
\hline
\end{tabular}

Hypothesis test

This study consists of four hypotheses with the results of the regression test for each equation presented in Table 3 . The regression test in this study is one-tailed because it has a directed hypothesis. The results of hypothesis testing are briefly presented in Table 5 . 
Table 5

Hypothesis Testing Results

\begin{tabular}{cccc}
\hline Hypothesis & Coefficient & Significance & Evidence \\
\hline H1 & $-4,281$ & 0,000 & Accepted \\
H2 & 4,483 & 0,0005 & Accepted \\
\hline
\end{tabular}

The first hypothesis states that corporate governance has a negative effect on expropriation practices. This hypothesis is supported if the regression coefficient is negative with a significance of $<5 \%$. Based on Table 5, the regression results show that the regression coefficient is negative $(-4,281)$ with a significant probability value at the $5 \%$ level $(0,000)$. Based on the regression results, it can be concluded that $H 1$ is supported because corporate governance has a negative effect on expropriation practices.

The results of this study are in line with several previous studies (Fakkriyah et al., 2017; Hamid et al., 2016; Lo et al., 2010) which state that the implementation of governance can reduce the practice of expropriation. The results of this study can confirm the application of agency theory, particularly type II agency theory (between controlling and non-controlling shareholders) which usually appears in companies whose ownership is concentrated. The results of this study have also answered that conventional governance mechanisms are considered insufficiently relevant to addressing agency problems in Asia so that another mechanism is needed to improve them, namely the existence of a governance index score that has been used in this study. The use of governance scores in this study can also be a relevant reference for assessing how the implementation of governance that has been implemented in the company can balance each stakeholder's rights and interests.

The second hypothesis states that family ownership will weaken the negative effect of corporate governance on expropriation practices. This hypothesis is supported if the governance regression coefficient (TK) is negative while the coefficient for $\mathrm{TK} * \mathrm{KK}$ has a significance value $<5 \%$. Based on Table 5 , the coefficient for $\mathrm{TK} * \mathrm{KK}$ is -4.281 (negative) while the coefficient for TK $* \mathrm{KK}$ is 4.483 (positive) with a significant probability value at the $5 \%$ level (0.00005). Based on the regression results, it can be concluded that H2 is supported because family ownership (KK) can weaken the negative influence of governance $(\mathrm{TK})$ on the practice of expropriation $(P E)$.

The results of this study are in line with the results of research conducted by Wirawan \& Diyanty (2014) which states that family ownership will hinder the application of governance in reducing the practice of expropriation. In companies whose ownership is dominated by families, controlling shareholders tend to maintain their dominance in the company, through their management as well as restrictions on governance practices (Classen et al., 2000; Doidge et al., 2007; Hamid et al., 2016). The principles of corporate governance which aim to provide equal treatment to all shareholders are not well implemented in companies with a high proportion of family ownership (Haque et al., 2011; Chauhan et al., 2016; Chhaochharia \& Laeven, 2009). Restrictions on governance practices ultimately limit the protection of shareholders, not controllers of expropriation practices.

\section{Conclusion}

The results of this study conclude that the practice of expropriation can be minimized by implementing good governance mechanisms within the company. In Indonesia, the Financial Services Authority has issued Financial Services Authority Circular Letter No. 32/2015 concerning Guidelines for Governance of Public Companies so that companies in Indonesia can maintain the implementation of good governance. Thus, every company can protect stakeholders by paying attention to each stakeholder's rights and interests to minimize expropriation practices that can harm non-controlling shareholders. In addition, the measurement of the governance score index was adopted from the OJK Circular No. 32/2015 concerning Guidelines for the Implementation of Corporate Governance for Public Companies has been proven to be one of the good governance mechanisms that can improve conventional governance mechanisms in reducing the practice of expropriation in Indonesia, which tends to concentrate companies. This study succeeded in proving that family ownership weakens the effect of corporate governance in reducing expropriation practices. This is because the controlling shareholder, in this case, the family will retain its control so that it can still benefit from non-controlling shareholders through expropriation practices so that the controlling shareholder will try to maintain its dominance in the company through its management. The controlling shareholder (family) will cover up

Rettob, G. B. N., Subekti, I., \& Mardiati, E. (2021). Effect of corporate governance on expropriation practices with family ownership as moderation variable. International Research Journal of Management, IT and Social Sciences, 8(3), 256-264. https://doi.org/10.21744/irjmis.v8n3.1611 
expropriation practices carried out by hampering the implementation of corporate governance so that corporate governance which aims to protect non-controlling shareholders from expropriation practices is not carried out properly. Conflict of interest statement

The authors declared that they have no competing interests.

\section{Statement of authorship}

The authors have a responsibility for the conception and design of the study. The authors have approved the final article.

Acknowledgments

We are grateful to two anonymous reviewers for their valuable comments on the earlier version of this paper. 


\section{References}

Baek, J. K. J., \& Park, K. S. (2004). Corporate Governance and Firm Value: Evidence from The Korean Financial Crisis. Journal of Financial Economics, 71(2), 265-

Bechuk, L., Kraakman, R., \& George, T. (1999). Stock Pyramids, Cross-Ownership, and Dual Class Equity: The Creation and Agency Costs of Separating Control from Cash Flow Rights. NBER Working Paper No. 6951.

Berle, A., \& Means, G. 1932. The Modern Corporation and Private Property. In Claessens, S., Djankov, S., and Lang L.H.P. 2000. The separation ownership and control in East Asian corporations. Journal of Financial Economics, 58, 81-112.

Chauhan, Y., Lakshmi, K. R., \& Dey, D. K. (2016). Corporate governance practices, self-dealings, and firm performance: Evidence from India. Journal of Contemporary Accounting \& Economics, 12(3), 274-289. https://doi.org/10.1016/j.jcae.2016.10.002

Chhaochharia, V., \& Laeven, L. (2009). Corporate governance norms and practices. Journal of Financial întermediation, 18(3), 405-431. https://doi.org/10.1016/j.jfi.2008.10.001

Claessens, S., Djankov, S., Fan, J., \& Lang, L. (2002). Disentangling the incentive and entrenchment effects of large shareholdings. Journal of Finance, 57(6), 2741-2771.

Claessens, S., Djankov, S., Fan, J., \& Lang, L.(2000). The Separation of Ownership and Control in East Asian Corporations. Journal of Financial Economics, 58, 81-112.

Doidge, C., Karolyi, G. A., \& Stulz, R. M. (2007). Why do countries matter so much for corporate governance?. Journal of financial economics, 86(1), 1-39. https://doi.org/10.1016/j.jfineco.2006.09.002

Du, J., He, Q., \& Yuen, S, W., (2013). Tunneling and The Decision To Go Private: Evidence from Hong Kong, Pacific Basin Finance Journal, 22(1), 50-68.

Fakkriyyah, D. D., Purnomosidhi, B., \& Subekti, I. (2017). Pengaruh Tata Kelola terhadap Praktik Ekspropriasi dengan Kebijakan Dividen sebagai Variabel Moderasi. Jurnal Ilmiah Manajemen, 7(3), 465-483.

Fan, J., \& Wong, T. J. (2002). Corporate Ownership Structure and The Informativeness of Accounting Earning in East Asia. Journal of Accounting and Economics, 33, 401-425.

Fernando, G. D., Schneible, R. A., \& Suh, S. (2013). Family Firms and Institutional Investors, Family Business Review, 27(4), $328-345$.

Hamid, M. A., Ting, I. W. K., \& Kweh, Q. L. (2016). The Relationship Between Corporate Governance and Expropriation of Minority Shareholders' Interest. Procedia Economics and Finance, 35(16), 99-106.

Hamid, M. A., Ting, I. W. K., \& Kweh, Q. L. (2016). The relationship between corporate governance and expropriation of minority shareholders' interests. Procedia Economics and Finance, 35, 99-106. https://doi.org/10.1016/S22125671(16)00014-9

Haque, F. T., Arun, \& Kirkpatrick, C. (2011). The Political Economy of Corporate Governance in Developing Economies: The case of Bangladesh. Research in International Business and Finance, 25(2), 169-182.

Hastori, S. H., Sembel, R., \& Maulana, T. N. A. (2015). Agency Costs, Corporate Governance and Ownership Concentration: The Case of Agro-industrial Companies in Indonesia. Asian Social Science, 11(18), 311-319.

Hung, M. (2000). Accounting Standards and Value Relevance of Financial Statements: An International Analysis. Journal of Accounting and Economics, 30(3), 401-420.

Jensen, M. C., \& Meckling, W. H. (1976). Theory of the Firm: Managerial Behaviour, Agency Cost and Ownership Structure. Journal of Financial Economics, 3, 305-360.

Kustiyaningrum, D., Nuraina, E., \& Wijaya, A. L. (2016) Pengaruh Leverage, Likuiditas, Profitabilitas, dan Umur Obligasi terhadap Peringkat Obligasi Perusahaan Terbuka yang Terdaftar di Bursa Efek Indonesia. Jurnal Akuntansi dan Pendidikan, 5(1), 25-40.

La Porta, R., Lopez-de-Silanes, F., \& Shleifer, A. (1999). Corporate Ownership Around the World. Journal of Finance, 54, 471-517.

Lo, A.W.Y., Wong, R.M.K. \& Firth, M. (2010). Can corporate governance deter management from manipulating earnings? Evidence from related-party sales transactions in China. Journal of Corporate Finance, 16(2), $225-235$.

Mitton, T. (2002). A cross-firm analysis of the impact of corporate governance on the East Asian financial crisis. Journal of financial economics, 64(2), 215-241. https://doi.org/10.1016/S0304-405X(02)00076-4

Rahman, Faizar \& Sunarti. (2017). Pengaruh Marketing Expense, Ukuran Perusahaan, dan Umur Perusahaan Terhadap Tingkat Profitabilitas Perusahaan. Jurnal Administrasi Bisnis, 52(1), 146-153.

Sari, R.C., Djajadikerta, H.G. \& Baridwan, Z. (2014). Asset Tunneling: Does Corporate Governance Matter? Evidence from Indonesia.

Shleifer, A., \& Vishny, R.W. (1997). A Survey of Corporate Governance.Journal of Finance, 52, 737-783.

Rettob, G. B. N., Subekti, I., \& Mardiati, E. (2021). Effect of corporate governance on expropriation practices with family ownership as moderation variable. International Research Journal of Management, IT and Social Sciences, 8(3), 256-264. https://doi.org/10.21744/irjmis.v8n3.1611 
Siregar, S. V., \& Utama, S. (2008). Type of earnings management and the effect of ownership structure, firm size, and corporate-governance practices: Evidence from Indonesia. The international journal of accounting, 43(1), 1-27. https://doi.org/10.1016/j.intacc.2008.01.001

Subekti, I. (2012). Relevansi Nilai atas Informasi Akuntansi, Struktur Kepemilikan Saham, dan Afiliasi Group Bisnis pada Perusahaan Publik di Indonesia. Jurnal Akuntansi dan Auditing Indonesia. 16(2), 147-158.

Villalonga, B., \& Amit, R. (2006). How do family ownership, control and management affect firm value? Journal of Financial Economics, 80, 285-417.

Wirawan, B., \& Diyanty, V. (2014). Kepemilikan Keluarga, Hubungan Politik dan Family Aligned Board terhadap Implementasi Tata Kelola Perusahaan. Jurnal Akuntansi dan Auditing Indonesia, 18(2), 139-155. 